Tropical Journal of Pharmaceutical Research April 2017; 16 (4): 781-785

ISSN: $1596-5996$ (print); 1596-9827 (electronic)

(C) Pharmacotherapy Group, Faculty of Pharmacy, University of Benin, Benin City, 300001 Nigeria.

All rights reserved.

Available online at http://www.tjpr.org

Original Research Article

http://dx.doi.org/10.4314/tjpr.v16i4.6

\title{
Emodin inhibits proliferation and invasion, and induces apoptosis in human esophageal cancer cell line ECA109
}

\author{
Chuan Zhao', Youyi $\mathrm{Wu}^{2}$, Fuyao $\mathrm{Li}^{2}$ and Xiaosheng $\mathrm{Jin}^{3 *}$ \\ ${ }^{1}$ Department of Pharmacy, Navy General Hospital PLA China, Beijing, 100048, ${ }^{2}$ Department of Medical Oncology, ${ }^{3}$ Department \\ Digestive Medicine, Ruian People's Hospital, Ruian, Zhejiang, PR China, 325200 \\ *For correspondence: Email: jinxsheng@126.com
}

Received: 24 November 2016

Revised accepted: 14 March 2017

\begin{abstract}
Purpose: To determine the anticancer effects of emodin in human esophageal carcinoma cell line ECA109.

Methods: Cell viability was determined by MTT assay, while cell invasion and apoptosis were measured by Transwell assay and flow cytometry, respectively. Expression levels of MMP-2, Bax, Bcl-2 and caspase-3 proteins were determined by Western blot.

Results: Flow cytometry data showed that the proportion of apoptotic cells was increased by emodin treatment. Apoptotic rates produced by 10, 20 and $50 \mu \mathrm{M}$ emodin were 13.9 $\pm 3.8,25.6 \pm 6.2$ and $39.8 \pm$ $7.7 \%$, respectively. Transwell assay data revealed concentration-dependent suppression of the invasive rate of ECA109 cells by emodin (10, 20 and $50 \mu \mathrm{M}$ ) was $30.0 \pm 4.5,56.0 \pm 6.8$ and $69.0 \pm 8.1$ $\%$, respectively. Furthermore, emodin treatment inhibited expressions of MMP-2 and Bcl-2 proteins, but induced the expression of Bax and caspase-3, when compared with control groups.

Conclusion: These results suggest that emodin inhibits cell proliferation and cell invasion, but induces cell apoptosis in human esophageal cancer cell line ECA109. Thus, emodin is a potential candidate for development of an effective chemotherapeutic agent against esophageal cancer.
\end{abstract}

Keywords: Emodin, Esophageal Cancer, Apoptosis, Cell invasion, Bax, Caspase-3

Tropical Journal of Pharmaceutical Research is indexed by Science Citation Index (SciSearch), Scopus, International Pharmaceutical Abstract, Chemical Abstracts, Embase, Index Copernicus, EBSCO, African Index Medicus, JournalSeek, Journal Citation Reports/Science Edition, Directory of Open Access Journals (DOAJ), African Journal Online, Bioline International, Open-J-Gate and Pharmacy Abstracts

\section{INTRODUCTION}

Esophageal cancer is a common malignant cancer worldwide. In the past few decades, incidence of esophageal carcinoma has significantly increased, with the result that it currently affects more than 450,000 people $[1,2]$. Metastasis and recurrence are two key factors responsible for the high mortality of esophageal carcinoma. Even with radical resection treatment, the five-year recurrence rate of esophageal cancer is still above $40 \%[3,4]$.

Emodin (1,3,8-trihydroxy-6-methylanthraquinone) is an active component of multiple traditional
Chinese medicinal herbs, and it possesses antiviral, antimicrobial, immunosuppressive, hepato-protective, and anti-inflammatory properties $[5,6]$. Recent studies indicated that emodin suppressed the proliferation of various tumors such as hepatoma, gastric cancer, breast cancer and colorectal cancer, in which multiple genes and signaling pathways are involved [710]. However, not much is known about the effect of emodin on the growth of esophageal cancer cells.

In the present study, the effect of emodin on apoptosis and invasion of human esophageal carcinoma cell line ECA 109, and the underlying 
mechanisms were investigated with a view to providing new insights into the treatment of esophageal cancer.

\section{EXPERIMENTAL}

\section{Cell culture}

Human esophageal cancer cell line ECA109 was obtained from GeneChem Company (Shanghai, China) and cultured at $37{ }^{\circ} \mathrm{C}$ in DMEM/F12 containing $10 \%$ fetal bovine serum (FBS) in a humidified atmosphere with $5 \% \mathrm{CO}_{2}$.

\section{Cell proliferation assay}

Standard tetrazolium bromide (MTT) assay was utilized to determine cell viability. Cells were seeded in 96-well plates $\left(5 \times 10^{3}\right.$ cells/well) with different concentrations of emodin $(0,10,20$ and $50 \mu \mathrm{M}$ ) for $24 \mathrm{~h}$. Thereafter, $50 \mathrm{~mL}$ MTT (Sigma) solution (2 $\mathrm{mg} / \mathrm{mL}$ in PBS) was added to each well, and the plates were incubated for $4 \mathrm{~h}$ at 37 ${ }^{\circ} \mathrm{C}$. To dissolve the resultant violet formazan crystals, each medium was removed, and the cells were incubated with $200 \mu \mathrm{L}$ dimethyl sulfoxide (DMSO) in the dark for $30 \mathrm{~min}$. Absorbance was measured at $570 \mathrm{~nm}$ in an automated microplate reader with DMSO as blank. All assays were performed in quintuplicates and repeated at least three times.

\section{Assay of apoptosis}

Cell apoptosis was assayed by Annexin-VFLUOS Staining Kit (Roche, USA) following the protocol provided by the kit manufacturer. The cells were then analyzed by flow cytometry using FACS Calibur (BD Biosciences, Bedford, MA, USA).

\section{Cell invasion assay}

Cell invasion was assayed in a 24-well Transwell chamber coated with Matrigel (BD Biosciences) on the upper surface of the membrane with a pore size of $8 \mu \mathrm{m}$ (Sigma). Cells $\left(1 \times 10^{4}\right.$ cells/well) were suspended in culture media (100 $\mu \mathrm{L}$, serum-free) and then seeded into the upper Transwell chamber. The lower chamber was covered with $10 \%$ FBS. After $24 \mathrm{~h}$ incubation, the invaded cells were fixed, stained and counted under a microscope (Olympus).

\section{Western blot}

Cells were obtained and washed twice with PBS. Ice-cold radio-immunoprecipitation assay buffer (RIPA, Beyotime, Shanghai, China), containing freshly-prepared $0.01 \%$ protease inhibitor cocktail (Sigma, Shanghai, China) was added so as to lyse the cells. Then the cells were incubated on ice for $30 \mathrm{~min}$, and centrifuged at $13,000 \mathrm{rpm}$ for $10 \mathrm{~min}$ at $4{ }^{\circ} \mathrm{C}$. The supernatant (20 - 30 $\mu \mathrm{g}$ of protein) was run on $10 \%$ SDSPAGE gel and electrophoretically transferred to a polyvinylidene fluoride membrane (Millipore, Shanghai, China). The membrane was then blocked with blocking reagent and incubated with primary antibodies against MMP-2, Bax, Bcl-2, caspase 3 and GAPDH (1: 1,000 dilution), followed by incubation with the secondary antibody (1: 1,000 dilution, Beyotime, Shanghai, China). The blot was visualized under enhanced chemiluminescence (ECL, Thermo Scientific, Shanghai, China).

\section{Statistical analysis}

All the results are presented as mean \pm standard deviation (SD, $\mathrm{n}=3$ ) and were analyzed statistically using SPSS18.0 software. Multiple comparisons were made by one-way ANOVA followed by Dunnett's test. $P<0.05$ was considered statistically significant.

\section{RESULTS}

\section{Emodin inhibits ECA 109 cell proliferation}

The effect of emodin on viability of human esophageal cancer ECA109 cells was examined by MTT assay. Compared with the control group, the three concentrations of emodin used $(10,20$ and $50 \mu \mathrm{M})$ significantly reduced ECA109 cell viability at $12,24,48$ and $72 \mathrm{~h}(p<0.05)$ in a concentration-dependent manner (Figure 1). Therefore, 10, 20 and $50 \mu \mathrm{M}$ concentrations of emodin were used in subsequent experiments.

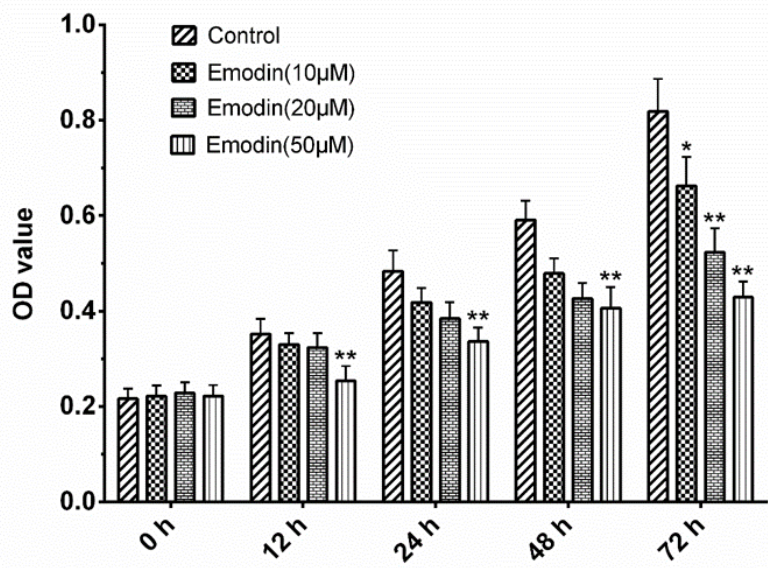

Figure 1: Effect of emodin on ECA 109 cell viability. Cells were treated with emodin $(10,20$ and $50 \mu \mathrm{M})$ for $0,12,24,48$ and $72 \mathrm{~h}$, and cell proliferation was measured by MTT assay. Data are presented as mean $\pm \mathrm{SD}(\mathrm{n}=6) ;{ }^{*} p<0.05 ;{ }^{* *} p<0.01$ compared with the control group

Trop J Pharm Res, April 2017; 16(4): 782 


\section{Emodin induces ECA 109 cell apoptosis}

The effect of emodin $(10,20$ and $50 \mu \mathrm{M})$ on ECA109 cell apoptosis was determined using flow cytometry (FCM). As presented in Figure 2, while most ECA109 cells remained alive in the control group, those incubated with different concentrations of emodin for $24 \mathrm{~h}$ displayed significant concentration-dependent increases in the percentage of apoptotic cells (both AV and PI-positive).
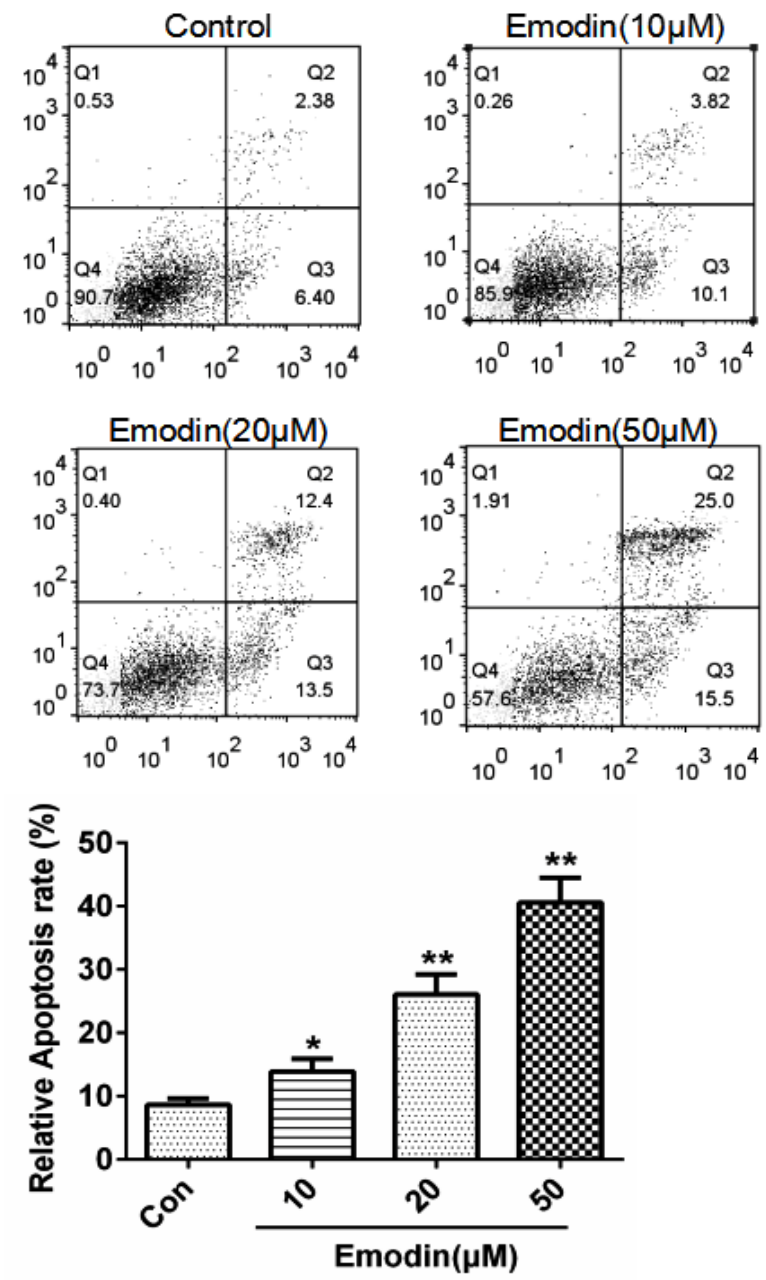

Figure 2: Effect of emodin on ECA 109 cell apoptosis. Cells were treated with emodin $(10,20$ and $50 \mu \mathrm{M})$ for $24 \mathrm{~h}$, and cell apoptosis was assessed by FCM. Data are presented as mean $\pm \mathrm{SD}(\mathrm{n}=6) ;{ }^{*} p<0.05 ;{ }^{* *} p<$ 0.01 compared with the control group

\section{Emodin suppresses invasion of ECA 109 cells}

Recent studies have demonstrated the central role of cell motility during tumor invasion and metastasis [11,12], hence, we investigated the effect of emodin on the invasive ability of ECA 109 cells using Transwell assay. As presented in Figure 3, Transwell migration assay demonstrated that emodin treatment significantly suppressed ECA 109 cell invasion in a concentration-dependent manner. The invasion rates of emodin - treated groups (10,20 and 50 $\mu \mathrm{M})$ were decreased by $30 \pm 4.5,56 \pm 6.8$ and $69 \pm 8.1 \%$, respectively.
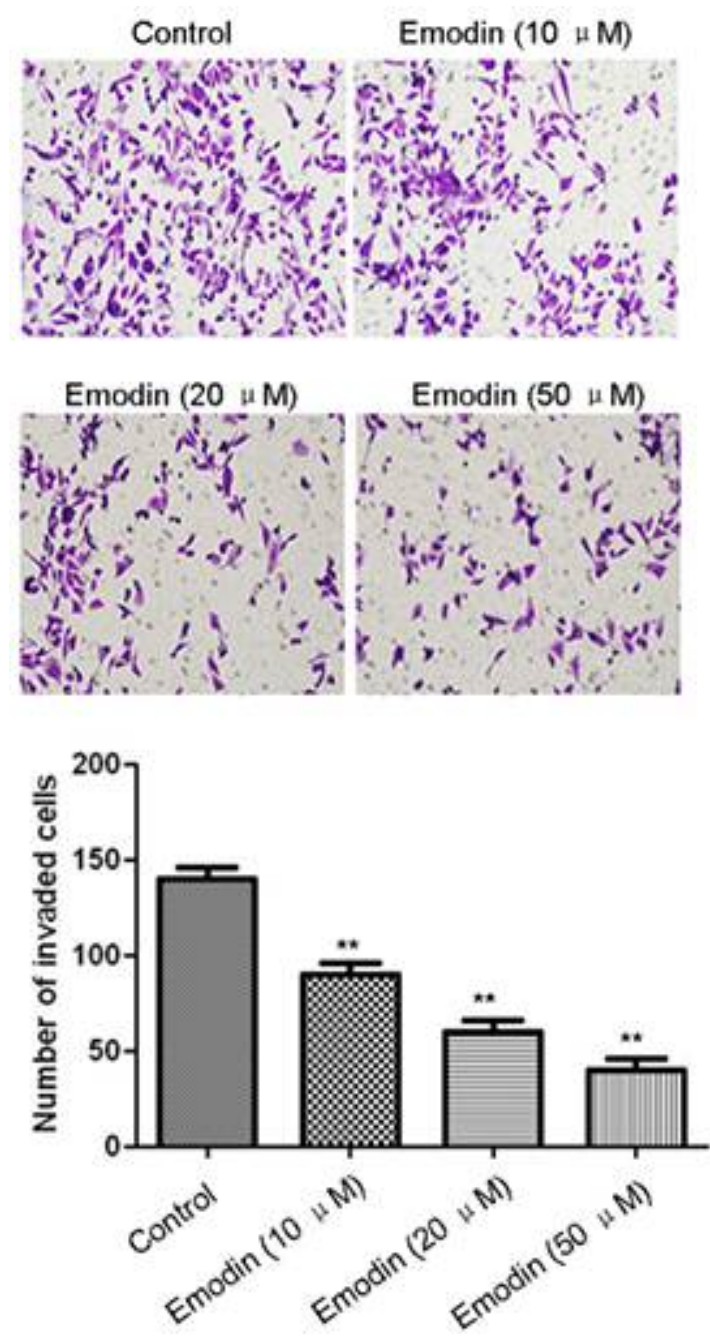

Figure 3: Effect of emodin on ECA 109 cell invasion. Cells were treated with emodin $(10,20$ and $50 \mu \mathrm{M})$ for $24 \mathrm{~h}$, and cell invasion was examined by Transwell assay. Data are presented as mean $\pm S D, n=6$; ${ }^{* *} p<$ 0.01 compared with the control group

\section{Emodin regulates expression of MMP-2, Bax, $\mathrm{Bcl}-2$ and caspase 3}

To elucidate the potential mechanism(s) involved in emodin-induced cell invasion, the expression levels of MMP-2, Bax, Bcl-2 and caspase 3 were measured by Western blot. It was found that MMP-2 and Bcl-2 protein levels were significantly reduced while those of Bax and caspase 3 were markedly elevated, indicating that emodin may inhibit ECA 109 cell invasion by down-regulating the expressions of MMP-2 and Bax and upregulating $\mathrm{Bcl}-2$ and caspase 3 expressions (Figure 4). 


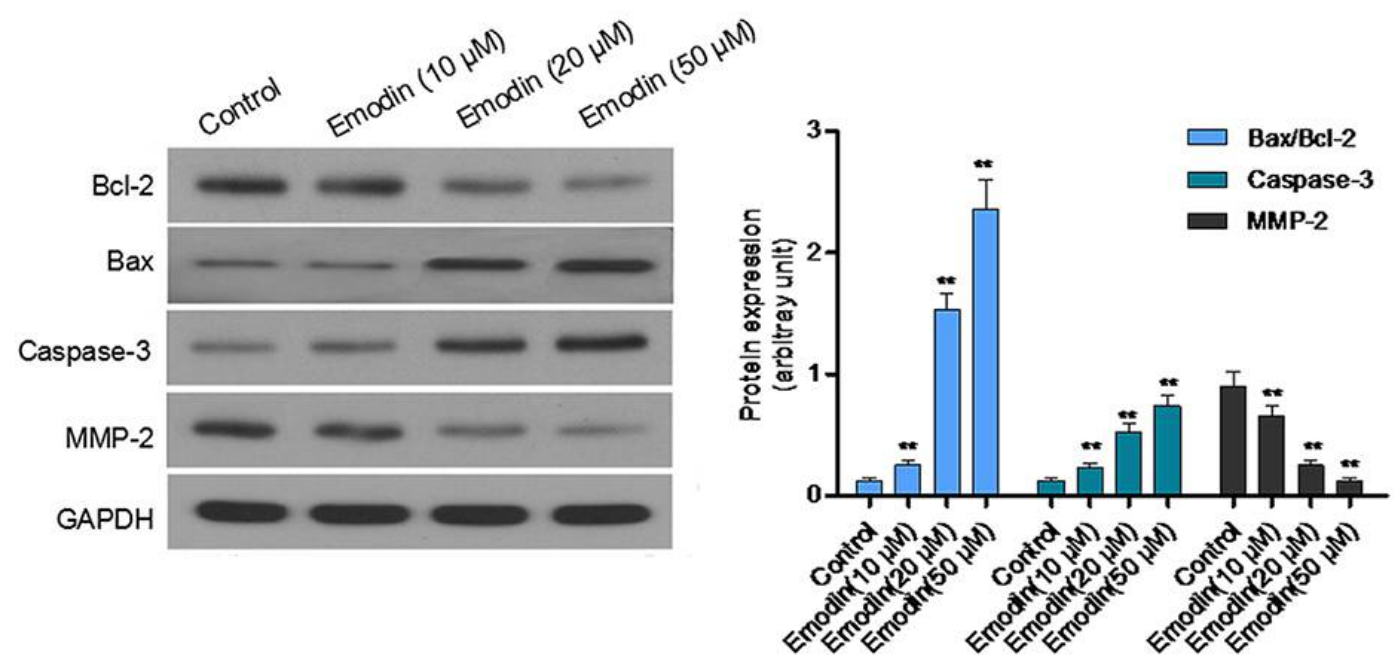

Figure 4: Effect of emodin on protein expressions of Bcl-2, Bax, Caspase-3 and MMP-2. Cells were treated with emodin $(10,20$ and $50 \mu \mathrm{M})$ for $24 \mathrm{~h}$, and protein expressions of Bcl-2, Bax, Caspase-3 and MMP-2 were measured by Western blot. Data are presented as mean $\pm \mathrm{SD}(\mathrm{n}=6) ;{ }^{* *} p<0.01$ compared with the control group

\section{DISCUSSION}

Esophageal cancer is a prevalent malignancy worldwide. In particular, China is one of the top countries with a high incidence of esophageal cancer. Results of analysis indicated that $95 \%$ of these esophageal cancers were in the form for squamous cell carcinoma (ESCC). Due to the poor prognosis of ESCC, it is important to elucidate the underlying mechanisms of OSCC, as well as its therapeutic targets. Traditional Chinese Medicinal (TCM) treatment, in conjunction with surgical operation, radiotherapy, or chemotherapy, can effectively alleviate cytotoxicity and strengthen immune functions. The combined use of Chinese and Western medicinal treatment is geared towards improving the quality of life and survival rate of OSCC patients by preventing recurrence and metastasis. Therefore, the search for effective anti-tumor products from Chinese medicinal herb is of vital importance to cancer therapy.

In the current study, it was demonstrated that different concentrations of emodin inhibited cell proliferation and invasion, and induced cell apoptosis in human esophageal cancer cell line ECA109. Emodin (10, 20 and $50 \mu \mathrm{M})$ significantly suppressed ECA109 cell proliferation in a concentration- and timedependent manner. In addition, emodin (10, 20 and $50 \mu \mathrm{M})$ also induced concentrationdependent cell apoptosis after $24 \mathrm{~h}$ treatment. The release of several apoptotic factors, such as cytochrome $\mathrm{c}$ and AIF, can be elicited through activation of the intrinsic mitochondrial pathway, which results in mitochondrial apoptosis and activation of the mitochondrial death pathway. Cytochrome $\mathrm{c}$ release facilitates formation of the apoptosome containing the adaptor Apaf-1 and the initiator caspase-9 in the presence of dATP, which in turn activates the downstream effector caspase-3 to induce cell apoptosis $[13,14]$. AIF can elicit cell apoptosis independent of caspase3 activation [15]. The results obtained in this study showed enhanced expression of activated caspase-3 proteins, indicating that emodin triggered caspase-dependent apoptosis which is activated by the mitochondrial death pathway and/or the death receptor pathway.

The first step in tumor cell invasion is the breakdown of the cytomembrane, which is known to be dependent on type IV collagen-degrading enzymes, mainly MMP-2 and MMP-9 [16]. Expressions of MMP-2 and MMP-9 have been reported to be associated with high potential of metastasis in several human carcinomas including esophageal cancer [17]. Results from Western blot demonstrated that emodin inhibited the expression of MMP-2, thus revealing the mechanism involved in the inhibition of cell invasion by emodin. This finding strongly suggests that emodin may be a promising drug target for different types of cancer.

\section{CONCLUSION}

The findings of this study show that emodin induces ECA109 cell apoptosis and inhibit cell invasion by regulating the activation and expressions of caspase-3, Bax/Bcl-2 and MMP2 , which are factors that play critical roles in esophageal cancer. Further studies are required to elucidate the possible mechanisms involved in these emodin-induced effects. Nevertheless, the findings of the present study show that emodin is 
a good candidate for development of a novel and effective therapy for esophageal carcinoma.

\section{DECLARATIONS}

\section{Acknowledgement}

None declared

\section{Conflict of Interest}

No conflict of interest associated with this work.

\section{Contribution of Authors}

The authors declare that this work was done by the authors named in this article and all liabilities pertaining to claims relating to the content of this article will be borne by them.

\section{Open Access}

This is an Open Access article that uses a funding model which does not charge readers or their institutions for access and distributed under the terms of the Creative Commons Attribution License (http://creativecommons.org/licenses/by/ 4.0) and the Budapest Open Access Initiative (http://www.budapestopenaccessinitiative.org/rea d), which permit unrestricted use, distribution, and reproduction in any medium, provided the original work is properly credited.

\section{REFERENCES}

1. Hatogai K, Kitano S, Fujii S, Kojima T, Daiko H, Nomura S, Yoshino T, Ohtsu A, Takiguchi Y, Doi T, Ochiai A. Comprehensive immunohistochemical analysis of tumor microenvironment immune status in esophageal squamous cell carcinoma. Oncotarget 2016.

2. Guan C, Zhang J, Zhang J, Shi H, Ni R. Enhanced expression of early mitotic inhibitor-1 predicts a poor prognosis in esophageal squamous cell carcinoma patients. Oncol Lett 2016; 12: 114-120.

3. Kimura M, Kuwabara Y, Ishiguro H, Tanaka T, Takeyama H. Bypass Operation as Palliation for Unresectable Esophageal Cancer: Selection of Suitable Patients. Hepatogastroenterol 2015; 62: 794-796.

4. Chen L, Chen J, Xu B, Wang Q, Zhou W, Zhang G, Sun $J$, Shi L, Pei $H$, Wu C, Jiang J. B7-H3 expression associates with tumor invasion and patient's poor survival in human esophageal cancer. Am J Trans/ Res 2015; 7: 2646-2660.
5. Yin JT, Wan B, Liu DD, Wan SX, Fu HY, Wan Y, Zhang $H$, Chen $Y$. Emodin alleviates lung injury in rats with sepsis. J Surg Res 2016; 202: 308-314.

6. Lin $W$, Zhong $M$, Yin $H$, Chen $Y$, Cao $Q$, Wang $C$, Ling $C$. Emodin induces hepatocellular carcinoma cell apoptosis through MAPK and PIJK/AKT signaling pathways in vitro and in vivo. Oncol Rep 2016.

7. Zhang $X$, Chen $Y$, Zhang $T, Y$ Zhang. Inhibitory effect of emodin on human hepatoma cell line SMMC-7721 and its mechanism. Afri Health Sci 2015; 15(1): 97-100.

8. Chihara T, Shimpo K, Beppu H, Yamamoto N, Kaneko T, Wakamatsu K, Sonoda S. Effects of Aloe-emodin and Emodin on Proliferation of the MKN45 Human Gastric Cancer Cell Line. Asian Pac J Cancer Prev 2015; 16(9): 3887-3891.

9. Huang $\mathrm{PH}$, Huang $\mathrm{CY}$, Chen $\mathrm{MC}$, Lee YT. Yue $\mathrm{CH}$, Wang $H Y$, Lin $H$. Emodin and aloe-emodin suppress breast cancer cell proliferation through ERa inhibition. Evid-Based Complement Alternat Med; 2013.

10. Niu H, Hu Z, Liu H, Hu G, Yang B, Wu S, Li F. Long noncoding RNA AK027294 involves in the process of proliferation, migration, and apoptosis of colorectal cancer cells. Tumor Biology; 2016: 1-9.

11. Luo $Q$, Kiangs $D$, Zhang $B$, Song $G$. Cell stiffness determined by atomic force microscopy and its correlation with cell motility. Biochim Biophys Acta 2016; 1860: 1953-1960.

12. Monet M, Poet M, Tauzin S, Fouque A, Cophignon A, Lagadic-Gossmann $D$, Vacher $P$, Legembre $P$, Counillon $L$. The cleaved FAS ligand activates the $\mathrm{Na}$ (+)/ $H(+)$ exchanger NHE1 through Akt/ROCK1 to stimulate cell motility. Sci Rep 2016; 6: 28008.

13. El ME, Ahmed MA, Ahmed AA. Attenuation of renal ischemia/reperfusion injury by acai extract preconditioning in a rat model. Life Sci 2015; 123: 3542.

14. Borghetti G, Yamaguchi AA, Aikawa J, Yamazaki RK, de Brito GA, Fernandes LC. Fish oil administration mediates apoptosis of Walker 256 tumor cells by modulation of p53, Bcl-2, caspase-7 and caspase-3 protein expression. Lipids Health Dis 2015; 14: 94.

15. Xue $Y$, Yang G, Wang C, Li X, Du G. Effects of shRNAMediated SOX9 Inhibition on Cell Proliferation and Apoptosis in Human HCC Cell Line Hep3B Mediated by Ultrasound-Targeted Microbubble Destruction (UTMD). Cell Biochem Biophys 2015; 73: 553-558.

16. Radenkovic $S$, Konjevic $G$, Jurisic V, Karadzic $K$, Nikitovic M, Gopcevic K. Values of MMP-2 and MMP-9 in tumor tissue of basal-like breast cancer patients. Cell Biochem Biophys 2014; 68: 143-152.

17. Li Y, Ma J, Guo Q, Duan F, Tang F, Zheng P, Zhao Z, Lu G. Overexpression of MMP-2 and MMP-9 in esophageal squamous cell carcinoma. Dis Esophagus 2009; 22: 664-667. 